\title{
The Psychogeographical Understanding of Identity in both Elizabeth Gilbert's Eat, Pray, Love and Mitch Albom's Tuesday's with Morrie
}

\author{
Aya Fayiz Zaki Al-Hasan ${ }^{1}$ \& Baker M. Bani-Khair ${ }^{1, *}$ \\ ${ }^{1}$ Department of English, Hashemite University, Jordan \\ *Correspondence: Department of English, Hashemite University, Jordan. E-mail: bakribakr@yahoo.com
}

Received: February 24, 2018 Accepted: March 5, 2018 Online Published: March 17, 2018

doi:10.5430/wjel.v8n1p1

URL: https://doi.org/10.5430/wjel.v8n1p1

\begin{abstract}
This study questions the effect of geography on the identity of the main characters in Elizabeth Gilbert's Eat, Pray, Love and Mitch Albom's Tuesdays with Morrie. This study also sheds light on the psychogeographical awareness regarding identity growth and maturity in the major characters due to geographical drives. It mainly applies Bachelard, Merlin, and Debord's Psychogeographical theories on both memoirs. It studies the effect of travelling to three different countries on the identity formation of Liz. It also shows the effect of going to another city to visit the dying professor on Mitch. It also shows how New York which is the place the two characters live in, affects their identity formation process. It is indeed an important factor on the identity formation of both characters. It is one of the essential elements in the formation of identity. Individuals still may change while they are in the same place but that does not decrease the importance of changing the place on one's identity.
\end{abstract}

Keywords: psychogeography, Bachelard, identity, Mitch, Liz, formation

“You can’t get away from yourself by moving from one place to another”.

Earnest Hemingway

The Sun Also Rises

\section{Introduction}

The question of whether identities change by moving from one place to another have been always raised by psychoanalysts. Harre in Gay's “What We're Made of' identified three attributes of the sense of self, one of which was psychogeographical: "[S]elf 1 is a sense of location relative to other positions; the body provides this, for our sense of self is “ordered by reference to our individual bodies” $(4,16)$ ” (578). He referred to the self as being located in the body. So wherever the body is, the sense of self is present. This is only one attribute of the sense of self that Harre' talked about. This attribute identifies the "self” according to its location "the body.” Yet the question remains whether the self that is located in the body changes according to the body's location or not.

Yasmin Mogahed in her book Reclaim Your Heart (2012) stated that humans seek a sense of safety, belonging, and perfection in this temporal world, but this quest would only hurt them because they were once home and now they are not, "[t]ornaway from our origin, we came across time and space to another world, alesser world. But in that separation, something painful happened. We were no longer with God in the physical space” (20). This painful journeyof "the fall of man" left a hole in all humans that grew as years passed (Freud, 1901, 1328). People tried to fill this void by moving from one place to another by buying new things and by doing many different activities: "[I]t is in this very quest to fill the hole that we stumbled. Each of us stumbled on different things. And many of us sought to numb the emptiness" (Mogahed,20). Liz in Eat, Pray, Love "stumbled" in her relationships, work, and spirit. She was wandering around aimlessly. On the other hand, Mitch in Tuesdays with Morrie "numbed" this emptiness by excessive work. 


\section{Psychogegraphical Experience: Analysis and Discussion}

Studying the impact of movement on characters in literary texts is relatively new. Guy Debord introduced the term "psychogeography" into literary analysis in the fifties. It "became a tool in an attempt to transform urban life, first for aesthetic purposes but later for increasingly political ends" (Coverley, 10). Other critics developed upon the works of Debord. To name a few, Gaston Bachelard's The Poetics of Space(1994), Marlin Coverly's The Art of Wondering(2012) and Psychogeography(2010)and Ewen Chardronnet's The History of Unitary Urbanism and Psychogeography at the Turn of the Sixties(2003).Debord defined psychogeography as "The study of the specific effects of the geographical environment (whether consciously organized or not) on the emotions and behavior of individuals" (qtd. in Chardronnet,4, Merlyn,10).

Many terms need to be explained before studying psychogeography. Guy Debord in his Internationale Situationniste (1958) introduced the concept of the "derive." He claims that his concept is different from the notions of the "journey" or "Stroll" (Debord, 62). Debord stated thatthederives "involve playful constructive behavior and awareness of psychogeographical effects" (ibid). Debord stated that in the derive people "drop their relations, their work, and leisure activities" in the purpose of "movement and action" (ibid). People "let themselves be drawn by the attractions of the terrain and the encounters they find there" (ibid). When people move, they become freer to do the things they wanted. They are no longer attached to a job, relation, or a material thing. They are free in their quest of self-discovery if there was one.

Liz in Eat, Pray, Love did the same. She canceled her relationship with her husband (got divorce), she left work (temporary), and she stopped her social activities. She allowed herself to accept the change that might result from this movement. She was also aware that there was a chance of nothing changing at all. She took the risk anyway. She did not only move away from her comfort zone, which is New York, but she also moved to three different countries, Italy, India, and finally Indonesia. The case of Mitch in Tuesdays with Morrie is different. He dropped his job in the sports magazine. Then, he left his city, New York, and moved to his professor's home in Massachusetts but only when he got engaged in the meetings with Morrie. His first visit was to see his professor. He was not aware of the outcomes of this visit. It was just paying a duty and nothing more.

Another theorist who defined the derive is Merlin Coverley. In a chapter entitled "Experimental Walking" Coverley quoted from Andy Merrifield the meaning of derive: "Derive was a continuous flow in which protagonists embarked upon a surrealist trip, a dreamy trek through varied Parisian passageways, forever on foot, wondering for hours" (183). The walking was aimless, just like Mitch's journey. He was not intending to change who he was or even to discover what he wants to do for the rest of his life. All he wanted was to pay his old professor a visit, a visit he promised sixteen years ago. It can be detected also in Liz's wandering in Italy without a guide. She did not plan where she wants to stay or what she wanted to do. She knew she was in need for a breakout of her zone. Even in India when she went to see Ketut without taking an appointment, she thought that he would be waiting for her, according to his prophecy. Liz and Mitch had their "purposeless drift through the city” (Moran, 183).

Another theorist who studied the effect of places on the identity of individuals in Gaston Bachelard. Bachelardanalyzed the way individual's experience and memories are attached to certain places. He claims that our houses are our first space where we had our daydreams and memories. Therefore, "our house is our corner of the world" (4). Housesare from where we carry the values to the outer world. The house here does not necessarily entail were we live but also "all really inhabited space bears the essence of the notion of the home" (5). Home for Gilbert was her workplace at first, then she found it in Ketut's house. Mitch's home was his professor's sociology classes, then his work for a little while, and last in his Jenin's heart. The change in the place of the house is due to change in the experiences the protagonists go through. This means that Gilbert found comfort, security, and happiness in her work at the beginning, but she could no longer sense that so she moved to another house. Mitch was happy in his sociology classes with his professor Morrie. Morrie's classes nurtured Mitch's “daydreams". When Mitch graduated and was "cast into the world", he searched for an alternative "cradle" (Bachelard, 7). He found it in his job at first. After going back to his professor's house, he settled in Jenin's heart.

Bachelard (1994) made an important statement: “An entire past comes to dwell in a new house” (5). This idea refutes the claim that says a person changes by movement; since they carry their past with them and dwell in the present. There would be no chance for change unless they dropped their past and lived their present. This is seen in Richard's advice to Liz in the Ashram. He told her to forgive herself for the mistakes of the past and move on. This advice is also common when trying to change something; move on or move forward. It conveys the act of geographical and psychological movement. Morrie taught Mitch how to move on emotionally, psychologically, and geographically. He taught him how to accept and say "good bye" to all the unpleasant feelings he once had, to all the experiences at 
work, love, and life. Letting go is an important practice in the process of movement. Bachelard (1994) claims that "[t]he old Saying 'We bring our lares with us' has many variations” (5). First, the lares are Gods in the ancient Rome. These Gods are worshiped every day at home. They are in a sense adding a spirit to the house. They are put in a corner or shelter and kept sacred. The same are the memories a person keeps. These memories that areformulated in any place are "housed" (10), and a good psychoanalyst in Bachelard's eyes is the one who may "turn his attention to this simple localization of memories" (8). It also goes with Freud's "the psychology of the unconscious"; meaning that the behavior is resulted from inherited experience that registered its emotional impact in the unconscious (1901, 1280). So the memory of the place is "not received in the same way every day. Psychically speaking, it is never objective" (Bachelard, 227).

Liz and Mitch make a good example. Liz grew up in rural Connecticut, a place with huge space that could have either allowed her to widen her horizons and think freely or made her short sighted. She was the younger child. She had only one sister: "That's my sister's name-Catherine. She is my one and only sibling... it was just the two of us, living in a farmhouse with our parents. No other kids nearby" (Gilbert, 88). This is why she had much freedom to do whatever she wanted away from the influence of the society. Living in rural Connecticut gave Liz a sense of security and stability. Bachelard (1994) claims that "[a] house constitutes a body of images that give mankind proofs or illusions of stability. We are constantly re-imagining its reality: to distinguish all these images would be to describe the soul of the house; it would mean developing a veritable psychology of the house" (17).

Thisalso meant more control from Liz's family side. She talked about how her sister controlled her. She was "mighty and domineering" (Gilbert, 88). While her parents gave her the freedom of choice, she was always controlled by her sister's power: "I lived in awe and fear of her; nobody else's opinion mattered but hers" (Gilbert, 88). Liz was giving her all for her sister so "she would not get mad" (Gilbert, 88). But this relationship affected Liz's identity later. Liz was always scared in relationships, and she was always giving her all to her beloved ones. She would give them her all. Like in her relationship with her husband, then her relationship with David. She was even scared to commit to Filipe after her world trip in search for balance.

Liz grew older and got married. She went to New York, with her husband. In New York she was still emotionally dependent on others. She was affected hugely by her relationship with her sister. They were contradictory. Liz was never prepared but did things and expected others to take the blame or correct what went wrong. Her sister Catherine was her opposite, she already preplans everything. Even though Liz got divorced, Catherine was there for her even when they were in different cities. Liz did not plan for her trips of self-discovery. This idea just came up in her mind one day, and she decides to leave everything behind and go. This is a careless act indeed for anyone who views Liz's story from outside. But inside, she was aware of the struggle between satisfying others on the expense of her own happiness. She even explains the coincidence that brought her into discovering herself, "I wanted to explore the art of pleasure in Italy, the art of devotion in India and, in Indonesia, the art of balancing the two. It was only latter, after admitting this dream that I noticed the happy coincidence that all these countries begin with the letter I" (Gilbert, 30). She considered this to be a sign of the need to discover herself, and her $I$.

Jean Hyppolite talked about "a first myth of outside and inside" (qtd in Bachelard, 212). He argued that "you feel the full significance of this myth of outside and inside in alienation, which is founded on these two terms" (qtd in Bachelard, 212). Liz's independence and detachment from the outside world helped in shaping her "interior shift[s]" (Gilbert, 23). She was making small steps in the direction of getting rid of everything that was holding her back so she could be freed from the inside. She was trying to assert her individuality as did Mitch. She used to justify every move she takes in to the outside world, so her interests and crushes had to have an explanation. She loved Italian because she found Italian "more beautiful than roses" but she "could never make the practical justification for studying it" (Gilbert, 23). She felt as if her thinking of Italian was irrational, as if she thought what others would think of her when she tries learning Italian. So she went to Italy where everyone speaks Italian, and there would be no external judgments on her learning the language and indulging in Italian food. Liz was eager to try new things and explore the unexplored. She had always wished to do crazy things outside her comfort zone but never did because of external constraints. In her divorce process, she fell in love with David. They "hiked to the top of things, swam to the bottom of other things, planned the journeys across the world ...” (Gilbert, 19).

The "spatial distinction between an inside and outside" have been argued by metaphysics (Rivkin and Rayan, 260). Bachelard (1994) claims that "everything takes form, even infinity" and in so being, individuals "transcend all situations, to give a situation of all situations" (212). He argues how the man is "here" and others are "there" in the world. But in this regard he is asserting the metaphysics in that [man] is in need to "mapping" his place in the world (Bachelard, 212). This takes us back to the existential and essential argument whether "existence precedes essence" 
or the other way around (Sartre, 1945, 3). Liz was trying to find her special place in the world. She went to Bali the first time because of work assignment. There she met Ketut who became her mentor. Ketut summarized to Liz what is going to happen for her in the next six to ten months. She accepted it as someone who might be right and might get it wrong.

During her second trip to Bali, she met Ketut again and stayed in his home. He offered her to be his secretary, and he will teach her everything about "Balinese meditation" (Gilbert, 224). He thought that "three months enough time to teach [her] Balinese meditation, find God for [her] this way," he says. "Maybe four months" (Gilbert, 224). The contradiction here is that she had spent more than ten years feeling out of place, and he expects her to meditate and find God within a short period of time in Bali. Liz was uncertain of who she is, or what she was going to do. She was out of place and did not know where she belonged. Liz portrayed the total opposite of what she noticed in Bali: "The whole idea of Bali is a matrix, a massive and invisible grid of spirits, guides, paths and customs. Every Balinese knows exactly where he or she belongs, oriented within this great, intangible map” (Gilbert, 227).

Liz's new friend in Bali, Mario, told her that the only way to be happy and find balance is by maintaining "himself -mentally and spiritually- at the intersection between a vertical line and horizontal one, in a state of perfect balance" (Gilbert, 227). In order for him to do this, he must "know exactly where he is located at every moment, both in his relationship to the divine and to his family here on earth. If he loses that balance, he loses his power" (Gilbert, 227). Liz was Living and doing exactly the opposite of Balinese visions of balance. She left her family for her search of identity. She neglected one essential element in finding balance. She realized "how far off the grid of balance [she had] fallen" (Gilbert, 227).

According to Derrida, it is not as easy as the metaphysics puts it to differentiate between what is inside and what is outside, yet it can be accomplished. Derrida noted that "it is the act of spatial differentiation that allows one to think of inside and outside... in the first place" (Rivkin and Rayan, 260). Liz spent the next months of her last trip to Indonesia living Ketut's prophecy. Ketut's instructions were external forces since they came from the outer space of Liz's self. Liz did not perceive this external guidance correctly. She was in loss until an inner power lifted her up and she made her mind to go in a journey of self-discovery. Ketut offered to teach Liz everything he knew, and which Liz might be interested in. Ketut was a positive force that somehow helped Liz choose Indonesia over other countries in her journey of self-discovery. The intrinsic forces were Liz's intuition and desire to believe a ninth generation medicine man "Ketut Liyer" (Gilbert, 26). Mitch, on the other hand, did not think of changing until an external power pushed him. He never thought of changing his identity until he went to see his professor in another city. But one wonders whether it was Ketut or Liz who initiated the self-discovery journey, or it was Morrie or Mitch who caused this identity formation process. It is also a question whether the external forces or the internal ones were the spark of the identity formation process.

Liz mentions the situations which are the same from outside, but from inside they are different. When she went back from her tours with Giovanni, she sits on her knees and prays. She gave the universe thanks for the miracle it gave her, the miracle of a new beginning, a second chance in life. At that time, she was alone in her rented room in Italy. Three years earlier, she found herself in "this exact same posture: on [her] knees, on a floor, praying" (Gilbert, 9). She was sobbing on her bathroom floor in her newly purchased apartment in the suburbs of New York. She was very desperate and feeling very lonely although she was married and her husband is in their bedroom. She was praying for her sense of being lost to end. She was praying for a miracle: "Everything else about the three years ago scene was different, though" (Gilbert, 9).

This change of inside and outside have also affected urban cities. Chardronnet (2003) Claims that "cities were losing their human dimensions" (3). The modernization of urban cities affected not only the places but also the psychology of its inhabitants. Mitch lived in New York and worked with movie stars and athletes that he did not care about and neither did they. Morrie on the opposite scene was "squeezing out every moment with his loved ones" while Mitch "spent many hours on things that meant absolutely nothing to me personally" (Albom, 42). Mitch was losing his "human dimension" (Chardronnet, 3). Since Morrie was suffering, he felt closer to people who suffer, he even shed tears in sympathy for them. But Mitch never cried for others. He "covered stories where people died" (Albom, 51). He "interviewed grieving family members". He "even attended the funerals" (Albom, 51). Mitch asked himself whether death was "the great equalizer, the one big thing that can finally make strangers shed a tear for one another" (Albom, 51). But he never actually changed even when he moved from one place to another. Liz was in New York not having an appetite for life. She was living like a robot doing the same things every day, not feeling anything. And other times she "wonder what I'm doing here, I admit it” (Gilbert, 60). Liz and Mitch travelled for personal reasons. They were driven by their strong emotions and needs. Psychogeography is "an individual process of drifting to know 
about your personal relation to the city or history" (Chardronnet, 11). Liz claims that she went to Italy to "experience pleasure" although "pure pleasure is not my cultural paradigm” (Gilbert, 60).

Psychogeography is not only limited to movements from one country or city to another. Psychogeography is also interested in the psychological impacts on individuals resulted from movements from one place in the house to another. Bachelard claims in "House and Universe" that houses and rooms in specific carry intimate relations to its reference. "[It] was reasonable to say we "read a house", or "read a room", since both room and house are psychological diagrams that guide writers and poets in their analysis of intimacy" (39). Morrie felt the most intimate inside his home and especially in his room. He loved every detail of his home. Every corner meant something to Morrie. Each place in Morrie's home has a memory connected to it. He wanted to die peacefully in his home. Mitch claimed that Morrie, while in coma, knew he was at home, "that his books and his notes and his small hibiscus plant were nearby". That is why Morrie surrendered and his soul moved "serenely" (Albom,188). Because Morrie knew he was in his house, his safe place, he died with peace. His house carried "all positive values of protection" (Bachelard, 17).

Morrie's home was an "artificial paradise” for him (Bachelard, 38). Bachelard referred to this paradise in Baudelaire Les paradisartificiels, a French poem that talks about a prisoner of winter who read books inside his house while winter was outside. This man felt the most comfortable and safe inside and winter's coldness and roughness stayed outside. Bachelard claims that if we carefully read the simple words of this French poem, "it soon brings tranquility of body and soul. We feel that we are living in the protective center of the house in the valley" (39). So places, especially homes and rooms, carry in them intimate feelings of safety.

The same place at different times may encompass different feelings and emotions. Bachelard explained the intimacy of house in the French poem in winter. The same house may encompass different emotions at a different time. Morrie loved his home but loved it even more when he became ill. Mitch did not notice the little details of Morrie's house until Morrie's time had come to an end: "I took in little details, things I hadn't noticed for all the times I had visited" (Albom, 181). Mitch continues describing how Morrie's house gave him feelings as if he was experiencing, it for the first time. It was the "newness of the image" that affected Mitch (Bachelard, xv). "The porch steps. The glass in the front door. I observed these things in a slow, observant manner, as seeing them for the first time" (Albom, 181). Since Morrie was getting weaker by time, Mitch was paying more attention to the place that might remind him of Morrie: "I walked slowly, taking my time, stepping on dead wet leaves that flattened beneath my feet" (Albom, 181). Mitch's comments on the plant that was beneath his foot in Morrie's home reflected the coming death of his professor.

The fourteenth Tuesday when it was time to "Say Good-bye”, Mitch tried to "hang on to whatever tradition" relating him with Morrie (Albom, 182). Hebrought food that Morrie was not able to chew any more. He put it in the kitchen where he saw "bottles of pills, lined up on the table, a small army of brown plastic soldiers with white caps" (Albom, 182). He went to the living room, the place "where Morrie and Ted Koppel had done their first interview" (Albom, 182). This brought Mitch back in time when he first saw his professor on T.V. It was the first time in sixteen years. He was anticipating the visit to his old professor as he was waiting to enter his room at the moment. Now he looked to see their "familiar spot" but an unfamiliar woman was standing next to Morrie, the thing that brought confusing feelings (Albom, 183). "Then I turned back hesitantly to the bedroom, and there he was, lying in bed, under the sheet" (Albom, 183). This scene brought back Morrie's words to Mitch's mind: "When you are in bed, you're dead" (Albom, 131). Mitch was attached psychologically to Morrie's house. He transposed "positive values" upon it (Bachelard, 17). He had an image of the "alive in his own head" (Bachelard, 225). This dream or image of the house "does not transpose a reality. It would be ridiculous, in fact, to ask the dreamer of its dimensions" (Bachelard, 228).

Hence, places are meaningless, and only people assign meaning to them. They refer to certain places with names that convey the meaning they have assigned to them, "[w]e create words to define our experiences and those words attendant emotions that jerk us around like dogs on a leash" (Gilbert, 325). For example, the house is only a building, but the house for the "prisoner ofwinter" is their "own nests" and "their beloved", while at other times they may be of different nature (Bachelard, 39). Bachelard claims that "everything comes alive when contradictions accumulate" (ibid). He explained this by giving the dark curtain as an example. It hangs from the sealing and being so dark it shows the whiteness of winter. Another example would be the museum, which is an old building that reflects a culture. But the museum for Liz in Italy meant the reconstruction of her identity after being torn. Liz had assigned this meaning to the place. She communicated with what happened inside this museum and related it to her identity development. Moreover, Morrie felt his room was his "own nest” (Bachelard, 39). He met Mitch each Tuesday and would sit in the same place which Mitch named "familiar spot" (Albom, 183). So overall, the place is neutral, it does 
not entail or affect, and it is an inner change that occurs when moving to new places. It is the act of assigning meaning to a place.

Moving from one place to another may be a discovery of oneself or an escape. It is debatable. Liz's journey to three countries may be seen as an escape from her bad divorce, her routine life, and her circle of friends and family, but others may argue it was a journey of self-discovery. Her movement to three different countries helped her in shaping and constructing her new identity. Without this act of movement, she would not have constructed her desired identity. Ruth William claims that "many women are choosing to travel as a way of tapping into the spiritual growth Gilbert experiences during her own travels" (616). Regardless of the purpose of her travel, she ended up achieving what she needed.

In Italy, she found beauty and nurtured her body, something she was not able to do in New York. In India she could gain her soul back by devoting herself to a higher power. She got to know "Him" in New York but she felt in need for a closer communication (Gilbert, 15). Yet I have to say that others may be able to stay in the same country and nurture their bodies and souls. So it depends on the individual to decide how much it is important to take the risk and travel. Gilbert herself said in Oprah show that "you don’t need to go and do exactly the things that I did... the only thing you need to do is ask yourself the questions I was asking myself" (Oprah.com, 2006). This is telling that the change happens psychologically rather than geographically. If people change their place and keep their mind shut, their trip would have been for nothing.

Moreover, psychogeography may be metaphorically applicable to movements from the mind to heart and vice versa. It may also apply to movements from heart to heart and mind to another mind. This can be seen in one of the most famous tales by Edgar Allan Poe The Cask of Amontillado (1846) (Habib, 463). This movement from heart to mind and vice versa is called the "Journey Motif." He related his Friend's old memory, which "has been preserved in his mind" with the depth of their relationship (Bachelard, 225). Montresor said: "My heart grew sick... for half a century now no human hand has touched them. May he rest in peace” (Poe, 72). No one was able to detect the journey until he confessed. This journey affected Montresor psychologically forever. It is a "psychological elasticity of an image that moves us at an unimaginable depths" (Bachelard, 6). When connecting these spatial elements to the events of the literary text, the significance of the motifs appear.

The motives of the journey may differ from its beginning to end. In Chaucer's The Canterbury Tales, the journey motif of the knights and pilgrims lead them into hard trials where they proved themselves heroes. These journeys did not have an end since "The Canterbury Tales is incomplete" (Grace, 17). This also applies to Liz when she was moving from one heart to another seeking at first fulfillment of her psychological needs like love and ending with a quest of self-realization. Changing her place in her beloved hearts indicates constant psychological motion. Mitch stayed in the same place and did not take the risk of movement, which may have contributed in his dependence on his professor in his identity formation process.

\section{Conclusion}

Places reflect the inner world of an individual. If the person is happy, the place will look much prettier. If the person is sad, the place would look gloomy. What the place reflects is not really what it is, it is only a reflection of oneself. People hold image of the place which is "alive in [their] head"(Bachelard, 225). Such an image of the house "lack[s] stability" because the essence of the place changes according to the psychology of the individual (Bachelard, 225).The place is not alive, people give places spirit, they unconsciously reflect their inner states on the place to what Freud calls "the psychology of the unconscious" (Freud, 1901, p. 1280). Measuring on the case of Liz and Mitch, many contradictory situations have occurred along their journey where they were in the same place but in totally different psychical states. Liz was on the bathroom floor in New York suffering from her marriage. She saw no way out. Liz's “imagination localizes and creates and recreates imaginary anatomies" (Bachelard, 225). A few weeks later, she was on the bathroom floor remembering her sobbing on New York's bathroom floor. But in the second scene she was much independent, happier, and balanced.

Mitch went to see his professor in another city. He went there every Tuesday but never noticed his professor's home. He was concentrating on his professor and never noticed the little details of his home. Once his professor's health condition started to withdraw, he began to notice these details. He started to cling on whatever may remind him of his professor. He even commented on these details conveying near death. The plants are "dead" and "flattened" just like his professor (Albom, 181). The weather was "cold and damp" (Albom,181), which reflected the dampness and heaviness of Mitch’s soul. He was sad and burdened with sorrow for losing his endeared professor. 
This does not decrease the effects of moving from one place to another on the psychology of the individual. These movements are indeed affective, and evidencefrom the two memoirs is convincing. If Liz stayed at New York in her apartment and at the same job, she would not have been the person she had become. This also applies to Mitch. If he had stayed in his city working the same job as sports columnist, he would have never become the Mitch he was once dreaming of becoming. It is noticeable that the whole journey the two protagonists made, moving from one place to another, committing to a family, job, and morals, rediscovering who they are and where they want to be, was a multilayered journey. One cannot deny the importance of one factor over another. Places do have huge impact on changing Liz's and Mitch’s identities.

\section{References}

Albom, M. (1997). Tuesdays with Morrie: an old man, a young man, and life's greatest lesson. New York: Doubleday.

Bachelard, G. (1994). The poetics of space: The classic look at how we experience intimate places (3rd ed.) (M. Jolas, Trans.). Boston: Beacon Press.

Chardronnet, E. (2003). The History of Unitary Urbanism and Psychogeography at the Turn of the Sixties. Retrieved 22 June 2011 from semaphore.blogs.com.

Coverley, M. (2010). Psychogeography. UK: Pocket Essentials.

Coverley, M. (2012). The Art of Wondering: The Writer as Walker. UK: Oldcastle Books Ltd

Debord, G. (1958). Theory of the Derive. In Internationale Situationniste. (pp. 62-66).

Freud, S. (1901). The Psychopathology of Everyday Life. In I. Smith (Editor), Freud- Complete Works. (pp. 1099-1347).

Gay, J. D. (2013). What We're Made of: Personhood in Graham Swift's Last Order. Christianity and Literature, 62(4), 565- 581. https://doi.org/10.1177/014833311306200407

Gilbert, E. (2006). Eat, pray, love: One woman's search for everything across Italy, India and Indonesia. New York: Viking.

Grace, D. (2010). The Canterbury Tales: Critical Reception. Critical Insights: The Canterbury Tales. (pp. 17-30). Retrieved on $5^{\text {th }}$ April. 2016 from Literary Reference Center.

Habib, M.A.R. (2005). A History of Literary Criticism: From Plato to the Present. UK. Blackwell Publishing. https://doi.org/10.1002/9780470752142

Mogahed, Y. (2012). Reclaim Your Heart: Personal Insights on Breaking Free from Life's Shackles. San Clemente, CA: FB.

Moran, J. (2009). Aimless Pleasures. New Statement183.4945, (pp. 17). Retrieved from Literary Reference Center.

Oprah.Com. (2006). Liz' Remarkable Journey.Oprah.com. Harpo, Inc. Retrieved from http://www.oprah.com/spirit/eat-pray-love-and-oprahs-book-club-announcement_1

Poe, E. A. (1846). The Cask of Amontillado. (pp. 68-72). Retrieved from https://americanenglish.state.gov/files/ae/resource_files/the_cask_of_amontillado.pdf

Rivkin, J., \& Micheal R. (1998). Rhetoric Phenomenology, Reader Response. Literary theory, an anthology. Malden, MA: Blackwell. (pp. 127-257).

Sartre, J.P. (1945). Existentialism and humanism. Retrieved on 6 Jan, 2017 from web.

Williams, R. (2014). Eat, pray, love: Producing the female neoliberal spiritual subject. Journal of Popular Culture 47(3), 613-633. Retrieved from Literary Reference Center. https://doi.org/10.1111/j.1540-5931.2011.00870.x

Wordsworth, W. (2017). BrainyQuote.com. Xplore Inc. Retrieved 16 February 2017 from https://www.brainyquote.com/quotes/quotes/w/williamwor151964.html 